\title{
Prediction of success of induction of labour: Bishop's score versus transvaginal sonographic parameters
}

\author{
Papa Dasari*, Sutharshika Thiyagalingam
}

Department of Obstetrics and Gynaecology, JIPMER, Puducherry, India

Received: 22 December 2020

Accepted: 03 February 2021

\section{*Correspondence:}

Dr. Papa Dasari,

E-mail: dasaripapa@gmail.com

Copyright: (C) the author(s), publisher and licensee Medip Academy. This is an open-access article distributed under the terms of the Creative Commons Attribution Non-Commercial License, which permits unrestricted non-commercial use, distribution, and reproduction in any medium, provided the original work is properly cited.

\begin{abstract}
Bishop's score is a standard method of pre-induction assessment of parameters to predict induction of labour. It is subjective and has interobserver variability and it does not take in to account the supra-vaginal cervix which forms more than $50 \%$ of cervical length. During the past 3 decades studies undertaken to find out a better predictor of labour induction found ultrasonographic assessment of cervix to be a better method. Cervical length, posterior cervical angle and head position are some of the parameters that were studied and compared with Bishops score. Among these posterior cervical angles of $>110^{\circ}$ and cervical length of $<2 \mathrm{~cm}$ are the best predictors for success of induction of labour. These parameters would help to explain the chances of vaginal delivery and the risk of undergoing caesarean section in an objective way.
\end{abstract}

Keywords: Bishop's score, Cervical length, Posterior cervical angle, Head position, Successful labour induction

\section{INTRODUCTION}

Induction of labour is a process by which vaginal delivery is anticipated by artificial means so as to mimic the normal labour events before the woman goes in to spontaneous onset of labour. It is necessary in $20 \%$ of pregnancies for termination of pregnancy at appropriate time to save life of mother or fetus and at times both. ${ }^{1}$ The success of induction of labour depends mainly on the status of cervix at the time of labour induction. ${ }^{2-4}$ It is essential to predict the success of vaginal delivery before contemplating on induction so as to counsel women regarding the progress and the failure or success of vaginal delivery.

Pre induction favorability of the cervix is traditionally assessed by Bishop's score since its description in $1964 .{ }^{5}$ This assessment is subjective and it shows high inter-and intra-observer variability. ${ }^{6,7}$ Recently ultrasound assessment of cervix and other parameters are reported to be better than Bishop's score. Ultrasonographic measurement of cervical length is an objective method for assessing cervical status. ${ }^{8,9}$ Transvaginal ultrasonographic measurements like cervical length, posterior cervical angle, and occipital position are being used to predict the success of induction of labour. Their applicability in routine obstetric practice is not yet been recommended. Some studies reported ultrasonographic examination is as good as Bishop's score, few reported inferior and others reported better predictive value. This review is intended to report on the recent studies comparing Bishop's score with transvaginal sonographic parameters in predicting success of induction of labour.

\section{DISCUSSION}

\section{Trans abdominal sonography (TAS)}

In 1986 a semi quantitative ultra-sonographic scoring system was proposed by O'Leary and Ferrell. ${ }^{10}$ They evaluated the contour, thickness of lower uterine segment, length of cervix and dilatation by 
transabdominal USG and concluded that both Bishop score and ultrasound predicts the chance of successful induction of labour. However, they found no advantage of ultrasound over Bishop score.

\section{Transvaginal sonography (TVS)}

The entire length of the cervix cannot be assessed effectively by clinical examination. Of all the components of Bishop Score, cervical length and cervical dilatation \& effacement (which are also indirect assessment of cervical length) are more closely associated with successful induction of labour. Introduction of the transvaginal ultrasound became the major advance in the imaging system to evaluate the cervical characteristics to predict the successful induction of labour. In fact, the supra vaginal portion of cervix is better assessed with USG than clinical examination. Cervical length is measured easily by recognizing Internal and external OS (Figure 1). Since effacement starts at internal OS and progress downwards to external OS initial stages of internal OS assessment will be difficult especially if $\mathrm{OS}$ is closed. Hence sonographic cervical assessment was explored in many studies.

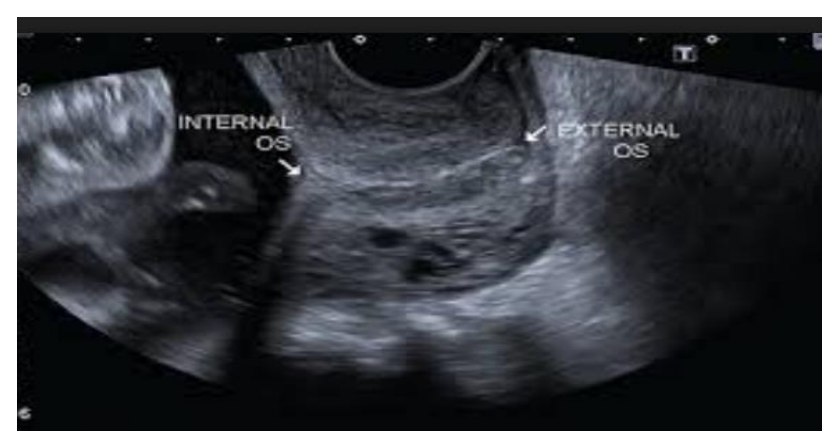

Figure 1: Cervical length measurement TVS.

\section{USG COMBINED SCORING SYSTEMS}

Various components of cervical sonography like cervical length, cervical dilation, fetal head position, posterior cervical angle, funneling and head perineal distance have been explored in many studies. Posterior cervical angle is measured between the long axis of the cervix and posterior wall of uterus at internal OS (Figure 2). Of late even stiffness of cervix has been studied by cervical elastography to certain extent.

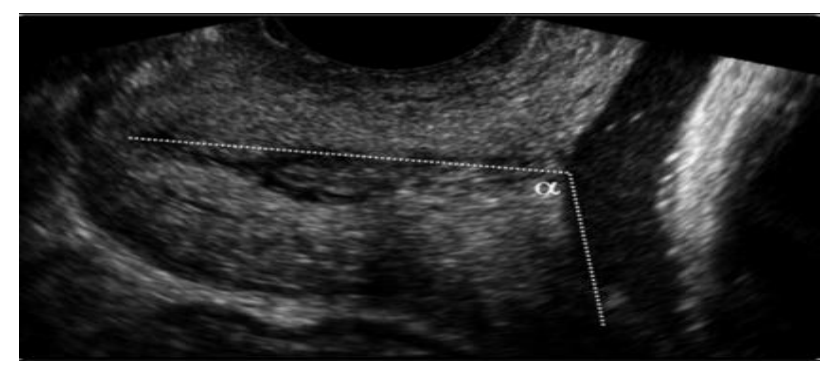

Figure 2: Posterior cervical angle measurement TVS.

\section{BISHOP'S SCORE ULTRASONOGRAPHIC PARAMETERS \\ VERSUS}

There were few systematic reviews on the role of transvaginal sonography in pre-induction assessment of cervix. Crane et al in 2006 reviewed the factors involved in the prediction of successful induction of labour. ${ }^{11}$ They concluded that increasing parity and age, lower weight, height and BMI and higher gestational age all were associated with successful induction of labour. They also noted that state of ripening correlated with successful induction and Bishop score is better in assessing cervical favorability. Even though they acknowledged the usefulness of sonographic cervical assessment in prediction of labour induction, they stated that the superiority of sonographic cervical assessment had yet to be identified. The sensitivity was $88 \%$ and specificity was $100 \%$ in predicting successful when posterior cervical angle $>70^{\circ}$ was combined with Bishop score $>5$. They concluded that best overall prediction is achieved by combining two methods and posterior cervical angle measurement should be confirmed by further studies in predicting outcome of labour. ${ }^{23}$

\section{BISHOP'S SCORE VS CERVICAL LENGTH (TABLE 1)}

A multicenter study was undertaken by Pandis et al involving 240 women to find out the relationship between the pre induction Bishop score with the cervical length using trans vaginal USG and to compare both the values in predicting successful vaginal delivery within 24 hours of induction. ${ }^{12}$ They demonstrated that both Bishop score and sonographically measured cervical length were significantly correlated with induction delivery interval. It was concluded that to predict the likelihood of vaginal delivery within 24 hours, cervical length measured by transvaginal sonography was a better parameter than Bishop score. They also observed that as the cervical length decreases, the likelihood of vaginal delivery increases. Women can be informed that when cervical length is less than $19 \mathrm{~mm}$, they would achieve vaginal delivery within 24 hours and when it is more than $31 \mathrm{~mm}$ there is $85 \%$ chance of remaining undelivered after 24 hours of induction. They concluded that transvaginal sonographic measurement of cervical length is best parameter for predicting the possibility of vaginal delivery within 24 hours of induction.

Gabriel et al in 2002 conducted a prospective study in 179 women, to predict the mode of delivery. They compared Bishop score and measurement of trans vaginal sonography in women undergoing indicated induction of labour at term. ${ }^{13}$ They highlighted that transvaginal sonographic assessment of the cervix prior to labour induction had not been shown to be of value when the Bishop score is $>5$. However, among women with low Bishop score, sonography of the cervix helps to differentiate between two subgroups with different obstetric prognosis. They concluded that cervical length 
of $>26 \mathrm{~mm}$ almost doubles the risk of caesarean section in a woman with unfavorable cervix.

In 2000, Ware and Raynor conducted a prospective observational study on 77 women, and compared the transvaginal cervical measurement with Bishop score in predicting the duration of labour and successful induction of labour at term. ${ }^{14}$ They found that cervical length with a cut off of $30 \mathrm{~mm}$, had a sensitivity of $91 \%$ and specificity of $92 \%$ in predicting vaginal delivery. Women with cervical length of $<3 \mathrm{~cm}$ had a shorter labour and more likely to deliver vaginally and women with Bishop score of $>4$ also had shorter labour and delivered vaginally. They concluded that the likelihood of vaginal delivery can be predicted by both parameters. However, they also stated that cervical length and parity were independent predictors of duration of labour and mode of delivery.

Bastani et al compared transvaginal ultrasonography with Bishop score for prediction of caesarean section after induction of labour. ${ }^{15}$ A total of 200 women with singleton pregnancies undergoing induction of labour were enrolled at term. The predictive value was determined by comparison of receiver operating characteristic curves (ROC) and equality of the area (AUC) under curve. The AUC for Bishop score was 0.39 (95\% CI 0.3-0.48) and for trans vaginal assessment of cervical length was 0.69 (95\% CI 0.29-0.47). There was a statistically significant difference of the ROC for cervical length, Bishop score and posterior cervical angle $(\mathrm{p}<0.001)$. There was no statistically significant difference in ROC area between Bishop score and posterior cervical angle.

Rozenberg et al conducted a study in 266 women to compare the pre induction Bishop score with transvaginal cervical length in predicting time to delivery. ${ }^{16}$ They concluded that Bishop score was better predictor than cervical length in predicting induction to delivery and vaginal delivery. The hazard ratio was (HR) 1.2 95\% CI 1.1-1.3. meaning higher the Bishop's score higher hazard to deliver vaginally. The limitation of the study was inclusion of heterogeneous population between 34 to 41 weeks. Since cervical ripening is a dynamic process that occurs in the third trimester before the onset of labour sonographic measurement may differ according to the gestational age. They also stated that cervical length is unlikely to be a marker for cervical ripening.

In 2006, Tan and colleagues conducted a prospective study in 249 women to compare the Bishop score and cervical length by transvaginal sonography. ${ }^{17}$ The aim of the study was mainly to assess their tolerability and ability to predict the need for caesarean delivery. Women tolerated transvaginal sonography than assessing Bishop Score. They found cervical length as well as Bishop score to be useful predictors of caesarean delivery following labour induction but cervical length of $>20 \mathrm{~mm}$ at term emerged as an independent predictor of caesarean delivery.
Rane et al in 2003, conducted a study in 382 women undergoing induction of labour in prolonged pregnancy. ${ }^{18}$ They have demonstrated that sonographically measured cervical length was better than Bishop score and concluded that nulliparous women with a cervical length of $<20 \mathrm{~mm}$ have an $80 \%$ chance of delivering within 24 hours of induction and $>30 \mathrm{~mm}$ have a $90 \%$ chance of remaining undelivered. They also concluded that parity was one of the independent predictors of outcome of the labour. In multipara $30 \%$ higher chance of delivering vaginally within 24 hours of induction than nullipara for the same score. Strobel et al in 2006 compared Bishop score and trans-cervical length in prolonged pregnancies and concluded that both can predict the time to onset of labour and delivery with same accuracy. ${ }^{19}$

In 2011 Park, conducted a study among 154 nulliparous women at term who were planned for induction of labour. ${ }^{20}$ The aim was to determine the requirement for prostaglandin administration for pre induction cervical ripening using sonograhically measured cervical length and Bishop score and compare both. Pre induction score was assessed by Bishop score and transvaginal sonography. They defined unfavourable cervix as having either Bishop score of $<4$ or cervical length of $>28 \mathrm{~mm}$. The primary outcome was successful induction and it was defined as achievement of active phase of labour within 22 hours of prostaglandin administration (diniprostone vaginal insert). It was concluded that cervical length measured by transvaginal sonography can reduce the need for induction agent by $50 \%$ without adversely affecting the outcome of induction when compared to assessment by Bishop score.

Bartha et al conducted a study in 2001 to 2002, involving 80 women who were randomized based on Bishop score or transvaginal ultrasound choice of induction agent. ${ }^{21}$ They considered the criteria of unripe cervix as Bishop score of $<6$ or cervical length of $>30 \mathrm{~mm}$ with cervical wedging of $<30 \%$ of the cervical length. They compared the Bishop score with the transvaginal ultrasound in pre induction cervical assessment for choice of induction agent. The primary outcome was percentage of the women who were induced with prostaglandin. They concluded that intracervical prostaglandin requirement as inducing agent has significantly reduced by $40-50 \%$ without affecting success of induction of labour in patients with the use of transvaginal ultrasound as a pre induction cervical assessment instead of Bishop score.

A prospective observational study was conducted by Gomez et al in 2006 involving 191 pregnant women undergoing labour induction to find out the relationship between the cervical length and Bishop score with duration of labour induction. ${ }^{8}$ They defined unripe cervix as either a cervical length of $>26 \mathrm{~mm}$ or Bishop score of $>6$. The outcomes measured were the duration of induction, delivery within 24 hours of induction and type of delivery. In this study, we found an association between the cervical length and Bishop score with the 
duration of induction. This study showed low Bishop Score and cervical length longer than $26 \mathrm{~mm}$ had a higher risk of delivery after 24 hours of induction. It was opined that sonographic assessment of cervix is useful in prediction of outcome of labour induction but its usefulness may be limited to unfavorable cervices.

The main advantage of sonographic cervical length assessment was less discomfort to patients. Few studies did not find transvaginal ultrasound superior to digital examination in pre induction cervical assessment. A study by Chandra et al in 2001 also compared transvaginal ultrasound with digital examination. ${ }^{22}$ There were 122 post term women involved in this study and all of them underwent transvaginal USG and digital assessment. It was found that digital assessment predicted success of labour induction. None of the USG parameters showed a significant association with successful labour induction or delivery within 24 hours. They also found certain clinical parameters like maternal age and weight in addition to cervical dilatation and effacement independently predicted successful labour induction. Even sonographic cervical length assessment produced conflict results there were attempts to look for other ultrasound parameters like posterior cervical angle and funneling of cervix. ${ }^{22-24}$ The angle between posterior uterine wall and cervical canal is called posterior cervical angle.

Table 1: Studies on Bishops score and transvaginal cervical length.

\begin{tabular}{|c|c|c|c|c|c|}
\hline $\begin{array}{l}\text { Name of } \\
\text { author and } \\
\text { year }\end{array}$ & $\mathbf{N}$ & $\begin{array}{l}\text { Parameters } \\
\text { studied }\end{array}$ & $\begin{array}{l}\text { Primary } \\
\text { outcome }\end{array}$ & Cut-off value & Result \\
\hline $\begin{array}{l}\text { Nikbakht et } \\
\text { al }^{22} 2016\end{array}$ & 148 & $\begin{array}{l}\text { Bishop score } \\
\text { vs CL }\end{array}$ & VD & $\begin{array}{l}\text { Bishop score }>4 \\
\text { CL }<20 \mathrm{~mm}\end{array}$ & $\begin{array}{l}\text { Trans vaginal CL is more reliable } \\
\text { than Bishop score in nulliparous } \\
\text { women }(p=0.016)\end{array}$ \\
\hline $\begin{array}{l}\text { Abdelazim } \\
\text { et } \mathbf{a l}^{23} \mathbf{2 0 1 2}\end{array}$ & 120 & $\begin{array}{l}\text { CL vs Mod. } \\
\text { Bishop score }\end{array}$ & VD & $\begin{array}{l}\mathrm{CL}<25 \mathrm{~mm} \\
\text { Bishop score }>5\end{array}$ & $\begin{array}{l}\mathrm{P} \text { value }<0.05 \text { for both } \mathrm{CL} \text { and } \\
\text { Bishop score }\end{array}$ \\
\hline $\begin{array}{l}\text { Groeneveld } \\
\text { et } \mathbf{a l}^{24} \mathbf{2 0 1 0}\end{array}$ & 110 & $\begin{array}{l}\text { CL vs Bishop } \\
\text { score }\end{array}$ & VD & Bishop score >3 & $\begin{array}{l}\text { Bishop score a better predictor of } \\
\text { vaginal delivery within } 96 \text { hours than } \\
\text { CL by TVS }\end{array}$ \\
\hline $\begin{array}{l}\text { Park et } \mathbf{a l}^{20} \\
2007\end{array}$ & 160 & $\begin{array}{l}\text { CL vs Bishop } \\
\text { score }\end{array}$ & $\begin{array}{l}\text { Failed } \\
\text { induction and } \\
\text { CD }\end{array}$ & $\mathrm{CL}>2.8 \mathrm{~cm}$ & $\begin{array}{l}\text { OR for Bishop score } 0.85(\mathrm{p}=\mathrm{NS}) \\
\text { OR for } \mathrm{CL} 2.8 \mathrm{~cm}(\mathrm{p}<0.005)\end{array}$ \\
\hline $\begin{array}{l}\text { Tan et } \text { al }^{17} \\
2007\end{array}$ & 249 & $\begin{array}{l}\text { CL vs Bishop } \\
\text { score }\end{array}$ & VD & $\begin{array}{l}\text { CL }<20 \text { mm Mod. } \\
\text { Bishop score } \geq 5\end{array}$ & $\begin{array}{l}\text { Sensitivity for TVS }(80 \%) \text { higher } \\
\text { than modified Bishop score }(64 \%)\end{array}$ \\
\hline $\begin{array}{l}\text { Rane et } \text { al }^{18} \\
2003\end{array}$ & 382 & $\begin{array}{l}\text { Bishop score } \\
\text { vs CL (TVS) }\end{array}$ & $\begin{array}{l}\text { Induction to } \\
\text { delivery } \\
\text { interval }\end{array}$ & Longer CL & $\begin{array}{l}\text { Sonographic CL better than Bishop } \\
\text { score or CL by vaginal examination } \\
\text { in predicting the outcome of } \\
\text { induction }\end{array}$ \\
\hline $\begin{array}{l}\text { Gabriel et } \\
\text { al }^{13} 2002\end{array}$ & 179 & $\begin{array}{l}\text { Bishop score } \\
\text { and CL (TVS) }\end{array}$ & $\begin{array}{l}\text { Risk of } \\
\text { caesarean } \\
\text { section }\end{array}$ & $\begin{array}{l}\text { Bishop score }<5 \\
\text { and } \mathrm{CL}<26 \mathrm{~mm}\end{array}$ & $\begin{array}{l}\text { In women with Bishop score }<5 \text {, the } \\
\mathrm{CL} \text { of }<26 \mathrm{~mm} \text { associated with lower } \\
\text { risk of caesarean section }\end{array}$ \\
\hline $\begin{array}{l}\text { Pandis et } \\
\text { al }^{12} \\
2001\end{array}$ & 240 & $\begin{array}{l}\text { Bishop score } \\
\text { vs CL }\end{array}$ & VD & $\begin{array}{l}\mathrm{CL}>28 \mathrm{~mm} \text { and } \\
\text { Bishop score }>3\end{array}$ & $\begin{array}{l}\text { CL a better predictor of vaginal } \\
\text { delivery and delivery within } 24 \\
\text { hours, sensitivity and specificity for } \\
\text { CL was } 0.87 \text { and } 0.71 \text { compared to } \\
0.58 \text { and } 0.77 \text { for Bishop score }\end{array}$ \\
\hline $\begin{array}{l}\text { Ware et } \text { al }^{14} \\
2000\end{array}$ & 77 & $\begin{array}{l}\text { Bishop score } \\
\text { vs CL }\end{array}$ & VD & $\begin{array}{l}\mathrm{CL}<3 \mathrm{~cm} \\
\text { Bishop score }>4\end{array}$ & $\begin{array}{l}\text { Both sonographically measured CL } \\
(p<0.001) \text { and Bishop score }(p \\
\text { value }<0.001) \text { predict likelihood of } \\
\text { VD }\end{array}$ \\
\hline
\end{tabular}

CL: Cervical length; VD: Vaginal delivery; CD: Caesarean delivery

\section{BISHOPS SCORE VS POSTERIOR CERVICAL ANGLE (TABLE 2)}

In 1991, Brown et al, conducted a pilot study in 50 patients who underwent induction of labour which included both primigravidae and multi gravidae ${ }^{[23]}$. These patients underwent pre induction cervical assessment by digital Bishop Score and transvaginal ultrasonography. Seven ultra sound parameters were examined, which included cervical length, width, position, dilation, application, lower segment thickness and cervical angle. It was measured using a protractor on hard copy picture at the level of internal OS. They found Posterior cervical angle to be more accurate than Bishop Score in predicting vaginal delivery. Posterior cervical angle correlated significantly with outcome of induction of labour. Patients experienced less discomfort with transvaginal ultrasound when compared to digital examination and 
this was statistically significant. Rizwana and collegues in 2016 studied 200 women and found that a CL of $3 \mathrm{~cm}$ and posterior cervical angle of more than 1000 as successful predictors of labour induction. ${ }^{25}$

Bastani et al in 2011 did not find posterior cervical angle as a better predictor of type of delivery following induction of labour. ${ }^{24}$ Posterior cervical angle of 100 degrees had a sensitivity $65 \%$, and a specificity of $72 \%$ for predicting vaginal delivery. The ability to predict caesarean section was not different that of Bishop score.

In 1994, Boozarjomehri et al compared digital evaluation with sonographic parameters. In addition to cervical length they studied cervical wedging (also known as funneling) and it was found that cervical funneling was significantly associated with a shorter latent labour and short duration of labour. ${ }^{25}$ Keepanasseril et al also studied the effect of cervical funneling on pre induction assessment of cervix in 2007 ${ }^{[26]}$. The managing physicians were blinded to sonographic parameters. But the cervical funneling was observed in only $22.7 \%$ of the women in the study. It may be due to inclusion of patients towards term during which funneling may disappear due to descent of head. Further studies are needed to study the effect of funneling in labour prediction.

Table 2: Studies comparing Bishop's score and posterior cervical angle and funneling.

\begin{tabular}{|c|c|c|c|c|c|}
\hline $\begin{array}{l}\text { Name of } \\
\text { author and } \\
\text { year }\end{array}$ & $\mathbf{N}$ & $\begin{array}{l}\text { Parameters } \\
\text { studied }\end{array}$ & $\begin{array}{l}\text { Primary } \\
\text { outcome }\end{array}$ & Cutoff value & Result \\
\hline $\begin{array}{l}\text { Rizwana et } \\
\text { al }^{25} 2016\end{array}$ & 200 & $\begin{array}{l}\text { CL, funneling } \\
\text { and posterior } \\
\text { cervical angle }\end{array}$ & $\begin{array}{l}\text { Successful } \\
\text { induction of } \\
\text { labour }\end{array}$ & $\begin{array}{l}\mathrm{CL}=3 \mathrm{~cm} ; \text { posterior } \\
\text { cervical angle }>100\end{array}$ & $\begin{array}{l}\text { CL and posterior cervical angle } \\
\text { were found to be statistically } \\
\text { significant in predicting successful } \\
\text { labour induction } \\
\text { (sensitivity and specificity for CL } \\
\text { was } 84 \text { and } 70.7 \% \text { and for posterior } \\
\text { cervical angle was } 85.6 \text { and } 66.7 \% \\
\text { respectively) }\end{array}$ \\
\hline $\begin{array}{l}\text { Keepananas } \\
\text { seril et } \text { al }^{26} \\
2007\end{array}$ & 138 & $\begin{array}{l}\text { CL and } \\
\text { posterior } \\
\text { cervical angle } \\
\text { (TVS) vs } \\
\text { Bishop score }\end{array}$ & $\begin{array}{l}\text { Successful } \\
\text { labour } \\
\text { induction }\end{array}$ & $\begin{array}{l}\text { CL }<3 \mathrm{~cm} \\
\text { Post. Cervical angle } \\
>100 \text { and } \\
\text { Bishop score }>3\end{array}$ & $\begin{array}{l}\text { OR for CL } 0.01 \text { (p value } 0.00) \text { for } \\
\text { post. Cervical angle } 1.041(\mathrm{p} \text { value } \\
0.03 \text { ) and for Bishop score } 0.57(\mathrm{p} \\
\text { value } 0.25)\end{array}$ \\
\hline $\begin{array}{l}\text { Paterson- } \\
\text { Brown et } \\
\text { al }^{23} 1991\end{array}$ & 50 & $\begin{array}{l}\text { Bishop score vs } \\
\text { seven USG } \\
\text { parameters } \\
\text { including CL } \\
\text { and posterior } \\
\text { cervical angle }\end{array}$ & VD & $\begin{array}{l}\text { Posterior cervical } \\
\text { angle }>70^{\circ} \\
\text { Bishop score }>5\end{array}$ & $\begin{array}{l}\text { Posterior cervical angle was more } \\
\text { accurate than Bishop score } \\
\text { (Kappa }=0.48 \text { vs } 0.21 \text { ) } \\
\text { No significant association between } \\
\text { CL and Bishop score or the } \\
\text { induction to delivery interval }\end{array}$ \\
\hline $\begin{array}{l}\text { Bastani et } \\
\text { al }^{24} 2011\end{array}$ & 200 & $\begin{array}{l}\text { CL and post. } \\
\text { cervical angle } \\
\text { (TVS) vs } \\
\text { Bishop score }\end{array}$ & $\mathrm{CD}$ & $>19 \mathrm{~mm}$ & $\begin{array}{l}\text { Specificity for Bishop score } \geq 6 \text { - } \\
85 \% \mathrm{CL} \geq 2.2 \mathrm{~cm} 82.5 \% \text { and } \\
\text { posterior cervical angle } \geq 120^{0} \text { - } \\
53.8 \%\end{array}$ \\
\hline
\end{tabular}

VD=Vaginal Delivery; $C D=$ Caesarean Delivery

\section{BISHOP'S VS CERVICAL LENGTH, POSTERIOR CERVICAL ANGLE AND HEAD POSITION (TABLE 3)}

Fetal head position by transabdominal ultrasound: The results were conflicting in literature about the effect of fetal head position in predicting delivery time.

Peregrine et al, conducted a study in 267 women undergoing labour induction and compared clinical and ultrasound parameters to predict the risk of caesarean delivery after induction of labour. ${ }^{27}$ They reported parity, height, body mass index, and transvaginal ultrasonographic cervical length to be accurate parameters in predicting the risk of caesarean delivery, and fetal head position was not a good predictive parameter.

In 2014, Gokturk et al conducted a prospective observational study among 223 women to evaluate the predictive value of sonographic cervical length, posterior cervical angle and fetal head position for determine successful induction of labour. ${ }^{28}$ They found that patients with occiput posterior position had longer labour time and this was not statistically significant. In 2016, Khazardoost and collegues found head position by USG and Cervical length of $16 \mathrm{~mm}$ had a sensitivity of $85 \%$ and bishop score of more than 5 had a sensitivity of $84 \% .^{28}$ 


\section{BISHOP SCORE VS CERVICAL LENGTH AND CERVICALWEDGING (TABLE 4)}

In 1998, Gonen et al, prospectively evaluated 86 women by digital cervical assessment and transvaginal ultrasonography to measure cervical length and wedging to predict success of induction and duration of labour. ${ }^{32}$ Successful induction and the duration of labour were significantly correlated with Bishop score and cervical length. Cervical wedging was associated with only with successful induction but not with duration of labour. However only the Bishop score and parity were the independent variables associated with successful induction and duration of labour on logistic regression model.

In 1994, Boozarjomehri et al attempted to explore the effect of sonographic cervical length and cervical wedging in duration of induced labour ${ }^{[30]}$. He included 53 patients who were planned for induction of labour. All of them underwent both sonographic and digital cervical evaluation. Both cervical wedging and cervical length which was measured by ultra sound were associated with duration of latent labour and total duration of labour. The $\mathrm{p}$ value for shorter latent $(15.9 \pm 1.7$ vs $34.1 \pm 3.8$ hours, $\mathrm{p}=0.0001)$ and total duration of labour $(22.0 \pm 1.8$ vs $38.3 \pm 3.6$ hours, $\mathrm{p}=0.0001$ ).

A meta-analysis by Hatfield et al in 2007 included a total

of 20 articles with 3101 participants for prediction of successful induction who used cervical wedging. A positive likelihood ratio of 2.64 and negative likelihood ratio of 0.64 . Were reported for cervical wedging. It was concluded that further-studies are necessary for evaluation on cervical wedging. ${ }^{31}$

Verhoeven et al in 2013 published a systematic review and meta-analysis on outcome of labour which included 31 articles on transvaginal sonographic assessment of cervical length and wedging. They reported that sonographic measurement of cervical length and cervical wedging at or near term have moderate capacity to predict the delivery outcome after labour induction. ${ }^{32}$ Hence, they concluded that assessment of cervical length and wedging of cervix which can be done easily with sonography but it has limited value in predicting the outcome of labour and in general, the accuracy of the test was too limited to justify its use in routine practice.

Table 3: Studies comparing Bishop score and fetal head position.

\begin{tabular}{|c|c|c|c|c|c|}
\hline $\begin{array}{l}\text { Name of } \\
\text { author and } \\
\text { year }\end{array}$ & No & Parameters studied & $\begin{array}{l}\text { Primary } \\
\text { outcome }\end{array}$ & Cutoff value & Result \\
\hline $\begin{array}{l}\text { Khazardoost } \\
\text { et } \mathbf{a l}^{28} \mathbf{2 0 1 6}\end{array}$ & 100 & $\begin{array}{l}\text { CL (TVS) and Fetal } \\
\text { position (TAS) vs } \\
\text { Bishop score }\end{array}$ & VD & $\begin{array}{l}16 \mathrm{~mm} \text { for } \mathrm{CL} \text { and } \\
\text { Bishop score } \geq 5\end{array}$ & $\begin{array}{l}85 \% \text { sensitivity and } 67 \% \\
\text { specificity for USG } 84 \text { and } 70 \% \\
\text { for Bishop }\end{array}$ \\
\hline $\begin{array}{l}\text { Gokturk et } \\
\text { al }^{28} 2014\end{array}$ & 233 & $\begin{array}{l}\text { CL and posterior } \\
\text { cervical angle (TVS) } \\
\text { fetal head position } \\
\text { (TAS) vs Bishop score }\end{array}$ & $\begin{array}{l}\text { Vaginal } \\
\text { delivery }\end{array}$ & $\begin{array}{l}\text { Posterior cervical } \\
\text { angle }>120^{0} \text { Bishop } \\
\text { score } \geq 5 \\
\text { CL }>25 \mathrm{~mm}\end{array}$ & $\begin{array}{l}\text { Bishop score-high sensitivity } \\
(76.4 \%) \text {, CL-high specificity } \\
(89.2 \%) \text { for prediction of } \\
\text { vaginal delivery, Posterior } \\
\text { cervical angle }>120^{0} \text { not } \\
\text { statistically significant }\end{array}$ \\
\hline $\begin{array}{l}\text { Peregrine et } \\
\mathrm{al}^{27} 2006\end{array}$ & 267 & $\begin{array}{l}\text { Clinical and USG } \\
\text { parameters } \\
\text { (CL and fetal head } \\
\text { position) }\end{array}$ & $\begin{array}{l}\text { Risk of } \\
\text { CD after } \\
\text { IOL }\end{array}$ & & $\begin{array}{l}\text { Both clinical (parity, height, } \\
\text { BMI) and sonographic CL were } \\
\text { accurate in predicting risk of } \\
\text { caesarean section but not fetal } \\
\text { head position }\end{array}$ \\
\hline
\end{tabular}

Table 4: Studies comparing Bishop score, cervical length and cervical wedging.

\begin{tabular}{|c|c|c|c|c|c|}
\hline $\begin{array}{l}\text { Name of } \\
\text { author and } \\
\text { year }\end{array}$ & No & $\begin{array}{l}\text { Parameters } \\
\text { studied }\end{array}$ & $\begin{array}{l}\text { Primary } \\
\text { outcome }\end{array}$ & Cutoff value & Result \\
\hline $\begin{array}{l}\text { Verhoeven } \\
\text { et } \mathbf{a l}^{32} 2013\end{array}$ & 31 & $\begin{array}{l}\text { Sonographic CL } \\
\text { and cervical } \\
\text { wedging } \\
\text { compared with } \\
\text { Bishop score }\end{array}$ & $\begin{array}{l}\text { Meta } \\
\text { analysis }\end{array}$ & $\begin{array}{l}\text { Sensitivity of CL for } \\
\text { the prediction of } \\
\text { caesarean delivery } \\
\text { ranged from } 0.14 \text { to } \\
0.92 \text { and specificity } \\
\text { ranged from } 0.35 \text { to } \\
1\end{array}$ & $\begin{array}{l}\text { CL and cervical wedging } \\
\text { measured sonographically at or } \\
\text { near term have moderate } \\
\text { capacity to predict the outcome } \\
\text { of delivery after induction of } \\
\text { labour }\end{array}$ \\
\hline
\end{tabular}

Continued. 


\begin{tabular}{|c|c|c|c|c|c|}
\hline $\begin{array}{l}\text { Name of } \\
\text { author and } \\
\text { year }\end{array}$ & No & $\begin{array}{l}\text { Parameters } \\
\text { studied }\end{array}$ & $\begin{array}{l}\text { Primary } \\
\text { outcome }\end{array}$ & Cutoff value & Result \\
\hline $\begin{array}{l}\text { Bartha et } \\
\text { al }^{21} 2005\end{array}$ & 80 & $\begin{array}{l}\text { CL and cervical } \\
\text { wedging (TVS) } \\
\text { Bishop score }\end{array}$ & $\begin{array}{l}\text { Need for } \\
\text { ripening and } \\
\text { caesarean } \\
\text { section }\end{array}$ & $\begin{array}{l}\text { Bishop score }<6, \mathrm{CL} \\
>30 \mathrm{~mm} \text { and } \\
\text { cervical wedging } \\
<30 \%\end{array}$ & $\begin{array}{l}85 \% \text { in Bishop score group } \\
\text { received inducing agent in } \\
\text { contrast to } 50 \% \text { in transvaginal } \\
\text { group (p value } 0.001 \text { ); rate of } \\
\text { caesarean section was similar in } \\
\text { both groups }\end{array}$ \\
\hline
\end{tabular}

CL: Cervical length

\section{CONCLUSION}

Bishop's score and trans vaginal sonographic parameters predict success of induction of labour but the transvaginal sonographic parameters are more objective and are useful especially in women with unfavorable cervix.

Bishop's Score is more subjective and the method is more painful when compared to transvaginal sonography. Of the transvaginal sonographic measurements cervical wedging and head position are not predictive of success of induction. Cervical length and posterior cervical angle are the best parameters that predict success of induction.

Funding: No funding sources

Conflict of interest: None declared

Ethical approval: Not required

\section{REFERENCES}

1. Zhang J, Yancey MK, Henderson CE. U.S. national trends in labor induction, 1989-1998. J Reprod Med. 2002;47(2):120-4.

2. Seyb ST, Berka RJ, Socol ML, Dooley SL. Risk of cesarean delivery with elective induction of labor at term in nulliparous women. Obstet Gynecol. 1999;94(4):600-7.

3. Yeast JD, Jones A, Poskin M. Induction of labor and the relationship to cesarean delivery: A review of 7001 consecutive inductions. Am J Obstet Gynecol. 1999;180 (3 Pt 1):628-33.

4. Vrouenraets FPJM, Roumen FJME, Dehing CJG, Van den Akker ESA, Aarts MJB, Scheve EJT. Bishop Score and Risk of Cesarean Delivery After Induction of Labor in Nulliparous Women: Obstet Gynecol. 2005;105(4):690-7.

5. Bishop Edward H. Pelvic scoring for elective induction. Obstet Gynecol. 1964;24:266-8.

6. Roman H, Verspyck E, Vercoustre L, Degre S, Col JY, Firmin JM et al. Does ultrasound examination when the cervix is unfavorable improve the prediction of failed labor induction? Ultrasound Obstet Gynecol Off J Int Soc Ultrasound Obstet Gynecol. 2004;23(4):357-62.

7. Rozenberg P. Intravaginal ultrasonography of the uterine cervix: hope in the Compaign against premature births. J Radiol. 1999;80;(5):421-9.
8. Gómez Laencina AM, Sánchez FG, Gimenez JH, Martínez MS, Valverde Martínez JA, Vizcaíno VM. Comparison of ultrasonographic cervical length and the Bishop score in predicting successful labor induction. Acta Obstet Gynecol Scand. 2007;86(7):799-804.

9. Pandis GK, Papageorghiou AT, Ramanathan VG, Thompson MO, Nicolaides KH. Preinduction sonographic measurement of cervical length in the prediction of successful induction of labor. Ultrasound Obstet Gynecol. 2001;18(6):623-8.

10. O'Leary J, Ferell R. Comparison of Ultrasonographic and digital cervical assessment. Obstet Gynecol. 1986;68:718-9.

11. Crane JM. Factors predicting labour induction success. a critical analysis. Clin Obstet Gynaecol. 2006;49(3):573-84.

12. Pandis GK, Papageorghiou AT, Otigbah CM, Howard RJ, Nicolaides KH. Randomized study of vaginal misoprostol (PGE (1)) and dinoprostone gel (PGE (2)) for induction of labor at term. Ultrasound Obstet Gynecol. 2001;18(6):629-35.

13. Gabriel R, Darnaud T, Chalot F, Gonzalez N, Leymarie F, Quereux C. Transvaginal sonography of the uterine cervix prior to labor induction. Ultrasound Obstet Gynecol. 2002;19(3):254-7.

14. Ware V, Raynor BD. Transvaginal ultrasonographic cervical measurement as a predictor of successful labor induction. Am J Obstet Gynecol. 2000;182(5):1030-2.

15. Bastani P, Hamdi K, Abasalizadeh F, Pourmousa P, Ghatrehsamani F. Transvaginal sonography compared with Bishop Score for predicting caesarean section after induction of labour. Int J Women's Health. 2011;3:277-80.

16. Rozenberg $\mathrm{P}$, Chevret S, Chastang C, Ville Y. Comparison of digital and ultrasonographic examination of the cervix in predicting time interval from induction to delivery in women with a low Bishop score. BJOG Int J Obstet Gynaecol. 2005;112(2):192-6.

17. Tan PC, Vallikkannu N, Suguna S, Quek KF, Hassan J. Transvaginal sonographic measurement of cervical length vs. Bishop score in labor induction at term: tolerability and prediction of Cesarean delivery. Ultrasound Obstet Gynecol Off J Int Soc Ultrasound Obstet Gynecol. 2007;29(5):568-73. 
18. Rane SM, Guirgis RR, Higgins B, Nicolaides KH. The value of ultrasound in the prediction of successful induction of labor. Ultrasound Obstet Gynecol Off J Int Soc Ultrasound Obstet Gynecol. 2004;24(5):538-49.

19. Strobel E, Sladkevicius P, Rovas L, De Smet F, Karlsson ED, Valentin L. Bishop score and ultrasound assessment of the cervix for prediction of time to onset of labor and time to delivery in prolonged pregnancy. Ultrasound Obstet Gynecol. 2006;28(3):298-305.

20. Park KH, Kim SN, Lee SY, Jeong EH, Jung HJ, Oh KJ. Comparison between sonographic cervical length and Bishop score in preinduction cervical assessment: a randomized trial. Ultrasound Obstet Gynecol Off J Int Soc Ultrasound Obstet Gynecol. 2011;38(2):198-204.

21. Bartha JL, Romero-Carmona R, Martínez-del-Fresno $\mathrm{P}$, Comino-Delgado R. Bishop score and transvaginal ultrasound for preinduction cervical assessment: a randomized clinical trial: Bishop score and TVS for preinduction cervical assessment. Ultrasound Obstet Gynecol. 2005;25(2):155-9.

22. Chandra S, Crane JM, Hutchens D, Young DC. Transvaginal ultrasound and digital examination in predicting successful labor induction. Obstet Gynecol. 2001;98(1):2-6.

23. Rizwana Habib Kant, Aquisa Bashir, Shruti Gupta. Study of Transvaginal Sonographic Assessment of Cervix in Predicting the Success of Labour Induction in Nulliparous Women www.jkscience.org. 2016.;18 (1):6-11.

24. Nikbakht R, Hemadi M. Transvaginal cervical length and Bishop score value in predicting successful labor induction with an emphasis on the parity Int $\mathbf{J}$ Pharmaceut Res Allied Sciences, 2016, 5(2):114-118

25. Faza MA. Sonographic assessment of the cervical length before induction of labor December 2012. Asian Pacific J Reproduction. 2012;1(4):253-7.

26. Groeneveld YJ, Bohnen AM, Van Heusden AM. Cervical length measured by transvaginal ultrasonography versus Bishop score to predict successful labour induction in term pregnancies. Facts Views Vis Obgyn. 2010;2(3):187-193.

27. Paterson-Brown S, Fisk NM, Edmonds DK, Rodeck $\mathrm{CH}$. Preinduction cervical assessment by Bishop's score and transvaginal ultrasound. Eur J Obstet Gynecol Reprod Biol. 1991;40(1):17-23.

28. Bastani P, Hamdi K, Abasalizadeh F, Pourmousa P, Ghatrehsamani F. Transvaginal ultrasonography compared with Bishop score for predicting cesarean section after induction of labor. Int $\mathbf{J}$ Womens Health. 2011;3:277-80.

29. Boozarjomehri F, Timor-Tritsch I, Chao CR, Fox HE. Transvaginal ultrasonographic evaluation of the cervix before labor: presence of cervical wedging is associated with shorter duration of induced labor. Am J Obstet Gynecol. 1994;171(4):1081-7.

30. Khazardoost S, Ghotbizadeh Vahdani F, Latifi S, Borna S, Tahani M, Rezaei MA, Shafaat M. Preinduction translabial ultrasound measurements in predicting mode of delivery compared to bishop score: a cross-sectional study. BMC Pregnancy Childbirth. 2016 Oct 28;16(1):330.

31. Keepanasseril A, Suri V, Bagga R, Aggarwal N. Preinduction sonographic assessment of the cervix in the prediction of successful induction of labour in nulliparous women. Aust N Z J Obstet Gynaecol. 2007;47(5):389-93.

32. Peregrine E, O'Brien $\mathrm{P}$, Omar R, Jauniaux E. Clinical and ultrasound parameters to predict the risk of cesarean delivery after induction of labor. Obstet Gynecol. 2006;107(2 Pt 1):227-33.

33. Gokturk U, Cavkaytar S, Danısman N. Can measurement of cervical length, fetal head position and posterior cervical angle be an alternative method to Bishop score in the prediction of successful labor induction? J Matern-Fetal Neonatal Med Off J Eur Assoc Perinat Med Fed Asia Ocean Perinat Soc Int Soc Perinat Obstet. 2014;1-6.

34. Boozarjomehri F, Timor-Tritsch I, Chao CR, Fox HE. Transvaginal ultrasonographic evaluation of the cervix before labor: presence of cervical wedging is associated with shorter duration of induced labor. Am J Obstet Gynecol. 1994;171(4):1081-7.

35. Hatfield AS, Sanchez-Ramos L, Kaunitz AM. Sonographic cervical assessment to predict the success of labor induction: a systematic review with metaanalysis. Am J Obstet Gynecol. 2007;197(2):186-92.

36. Verhoeven CJM, Rückert MEPF, Opmeer BC, Pajkrt E, Mol BWJ. Ultrasonographic fetal head position to predict mode of delivery: a systematic review and bivariate meta-analysis. Ultrasound Obstet Gynecol Off J Int Soc Ultrasound Obstet Gynecol. 2012;40(1):9-13.

Cite this article as: Dasari $\mathrm{P}$, Thiyagalingam $\mathrm{S}$.

Prediction of success of induction of labour: Bishop's score versus transvaginal sonographic parameters. Int J Reprod Contracept Obstet Gynecol 2021;10:12518. 